\title{
THE ANTHELMINTIC EFFECTS OF ETHANOL EXTRACT OF CURANGA FEL-TERRAE LEAVES ON ASCARIDIA GALLI
}

\author{
POPI PATILAYA ${ }^{1 *}$, DADANG IRFAN HUSORI ${ }^{2}$, IMAM BAGUS SUMANTRI ${ }^{1}$ \\ ${ }^{1}$ Department of Pharmaceutical Biology, Faculty of Pharmacy, Universitas Sumatera Utara, Medan, Indonesia. ${ }^{2}$ Department of \\ Pharmacology, Faculty of Pharmacy, Universitas Sumatera Utara, Medan, Indonesia. Email: popi.patilaya.usu.ac.id
}

Received: 03 October 2016, Revised and Accepted: 07 December 2016

\section{ABSTRACT}

Objective: This study was to investigate the anthelmintic effects of ethanol extract of Curanga fel-terrae leaves on Ascaridia galli.

Methods: Extract of $C$. fel-terrae was prepared by percolating the dried powder of the plant leaves. To observe anthelmintic effects, $A$. galli was exposed to the plant extract solutions in different concentrations at room temperature for 72 hrs. Sodium chloride $0.9 \%$, sodium carboxymethyl cellulose $0.5 \%$, and albendazole $0.1 \%$ were served as negative control, solvent control, and positive control, respectively. The anthelmintic effects were determined by observing the time taken for paralysis and the time taken for death of $A$. galli during experiment.

Results: The results demonstrated that there were no different effects between negative and solvent controls. However, the ethanol extract of C. fel-terrae leaves exhibited significantly paralysis and death effects toward A. galli. The plant extracts at the concentration of $100 \mathrm{mg} / \mathrm{ml}$ showed similar anthelmintic effects with albendazole $0.1 \%$. This study also indicated that the paralysis and death effects of plant extract were shorter when the worms exposed with the concentration above of $100 \mathrm{mg} / \mathrm{ml}$.

Conclusion: This study indicated that the ethanol extract of $C$. fel-terrae leaves has potential anthelmintic effects on A. galli.

Keywords: Curanga fel-terrae, Ascaridia galli, Anthelmintic, Helminthiasis, Ascariasis.

(C) 2017 The Authors. Published by Innovare Academic Sciences Pvt Ltd. This is an open access article under the CC BY license (http://creativecommons. org/licenses/by/4. 0/) DOI: http://dx.doi.org/10.22159/ajpcr.2017.v10i3.15504

\section{INTRODUCTION}

The World Health Organization reported that ascariasis is commonly parasitic infection disease of human with highest cases occur in tropical and subtropical countries. It is estimated around 60,000 people deaths by severe ascariasis infections, mainly in children [1]. Ascariasis also remains a health problem in Indonesia with the frequency cases about $75 \%$. Because of chronic ascariasis, children experience impaired growth and development due to decreased food intake [2]. Arizono et al. have studied that human ascariasis is a result of infection with pig-derived ascaris such as Ascaris lumbricoides, Ascaris suum, and Ascaridia galli [3].

The emergence of helminthes resistance to currently available anthelmintic agents leads to an increasing of natural anthelmintic demand [4].

Curanga fel-terrae (Lour.) Merr. which is known as Pugun tanoh or poguntano by Indonesian people belongs to family Linderniaceae $[5,6]$. The leaf of plant is traditionally used for helminthiasis treatment [7]. Preliminary study indicated that the leaf ethanol extract of $C$. fel-terrae has potential anthelmintic activity against an earthworm, Pheretima phostuma. This effect may due to the presence of phytochemical compounds such as flavonoids, saponins, tannins, glycosides, and dan steroids [8]. However, anthelmintic effects of the leaf ethanol extract of Indonesian C. fel-terrae on human parasitic worms have not been studied.

This work was to study the anthelmintic effects of the leaf ethanol extract of $C$. fel-terrae against A. galli. Although A. galli is the common helminth parasites in fowls [9], but this worm has similarity with A. lumbricoides in morphological and physiological properties [10]. Because of this reason, A. galli is used as animal model in our experiment.

\section{MATERIALS AND METHODS}

Plant materials

Leaves of C. fel-terrae were collected from Dairi District, North Sumatra Province, Indonesia. The species was authenticated and deposited by the Herbarium Department of Indonesian Institute of Sciences.

\section{Chemicals}

Chemical used in this study namely $96 \%$ ethanol, saline, and sodium carboxymethyl cellulose (Na-CMC) were purchased from Merck, UK. Standard albendazole was obtained from Indofarma Pharmaceutical Industry, Indonesia.

\section{Preparation of plant extract}

The cleaned leaves of $C$. fel-terrae were dried on oven with air circulation at $40^{\circ} \mathrm{C}$ and then powdered with electrical grounder. The dried leaf powder was extracted by percolating with $96 \%$ ethanol at room temperature. Filtrate was then concentrated in a rotary evaporator at $40^{\circ} \mathrm{C}$ to obtain the crude extract of plant leaves.

\section{Phytochemical screening}

Phytochemical screening method from Tiwari et al. was adopted to identify chemical compounds of the ethanol extract of $C$. fel-terrae leaves, such as alkaloids, flavonoids, glycosides, saponins, tannins, and terpenoids/steroids [11].

\section{Evaluation of anthelmintic effects}

A. galli were obtained from a local slaughterhouse in Medan, Indonesia. The worms were identified by the Zoology Department of Universitas Sumatera Utara. Before experiment, A. galli were acclimated in saline at room temperature for $1 \mathrm{hr}$. To investigate anthelmintic effects, the worms were divided into six groups in which each group contain three worms. Group I was exposed to saline (negative control), Group II was 
Table 1: Anthelmintic effects of the ethanol extract of $C$. fel-terrae leaves on $A$. galli

\begin{tabular}{lll}
\hline Treatment & Time taken for paralysis $(\mathbf{h r}) \pm$ SD & Time taken for death $($ hr) \pm SD \\
\hline Saline & $30.78 \pm 1.59^{*}$ & $38.03 \pm 0.33^{*}$ \\
Na-CMC $0.5 \%$ & $30.74 \pm 0.53^{*}$ & $38.08 \pm 0.18^{*}$ \\
Ethanol extract $(100 \mathrm{mg} / \mathrm{ml})$ & $5.08 \pm 0.87$ & $10.47 \pm 0.32$ \\
Ethanol extract $(200 \mathrm{mg} / \mathrm{ml})$ & $3.96 \pm 0.28$ & $8.39 \pm 0.84^{*}$ \\
Ethanol extract $(300 \mathrm{mg} / \mathrm{ml})$ & $2.49 \pm 0.09^{*}$ & $6.93 \pm 0.57^{*}$ \\
Albendazol $0.1 \%$ & $4.61 \pm 0.47$ & $10.26 \pm 1.01$ \\
\hline
\end{tabular}

All data are presented as the average value of three replicates $(\mathrm{n}=3) .{ }^{*} \mathrm{p}<0.05$ compared with albendazole $0.1 \%$, SD: Standard deviation, C. fel-terrae: Curanga fel-terrae, A. galli: Ascaridia galli

exposed to Na-CMC $0.5 \%$ in saline (solvent control), and Group III was exposed to albendazole $0.1 \%$ (positive control). Groups IV-VI were separately exposed to the ethanol extract of $C$. fel-terrae leaves at the different doses $(100,200$, and $300 \mathrm{mg} / \mathrm{ml})$. The anthelmintic effects were evaluated by observing the time taken for paralysis, and the time taken for death of the worms at room temperature for $72 \mathrm{hrs}$.

\section{Statistical analysis}

All data were expressed as mean \pm SD. The data of each group were statistically analyzed using analysis of variance followed by post hoc test Tukey honest significant difference multiple comparison tests. Values were classified as significantly different if $\mathrm{p}<0.05$.

\section{RESULTS}

\section{Phytochemical compounds}

The results of phytochemical test indicated that the leaf ethanol extract of $C$. fel-terrae contain flavonoids, glycosides, saponins, tannins, and steroids.

\section{Anthelmintic effects}

As shown in Table 1, there were no different effects on A. galli between saline (negative control) and Na-CMC 0.5\% (solvent control). During observation, the ethanol extract of $C$. fel-terrae leaves significantly produced paralysis and death effects toward A. galli compared with these controls. The plant extract at the concentration of $100 \mathrm{mg} / \mathrm{ml}$ have similar anthelmintic effects with albendazole $0.1 \%$. In addition, the paralysis and death times were shorter when on A. galli exposed to the plant extract at concentrations of $200 \mathrm{mg} / \mathrm{ml}$ and $300 \mathrm{mg} / \mathrm{ml}$. The results also indicated that the time taken for paralysis and the time taken for death on the worms declined with the increasing concentrations of the plant extract.

\section{DISCUSSION}

This study identified the presence of flavonoids, glycosides, saponins, tannins, and steroids in the leaf ethanol extract of C. fel-terrae. Few compounds of this plant leaves such as flavonoid glucoronides [12], dehydrobryogenin glycoside, cucurbitacin [13,14], triterpenoid saponins [15], and $\beta$-sitosterol [16] also isolated by other researchers. The C. fel-terrae also contain acid compounds mainly heptadecanoic acid, butanedioic acid, docosanoic acid, and hydroxycinnamic acid [17]. Those compounds may contribute to anthelmintic effects of the plant extract on human parasitic worms $[18,19]$.

Our study also noted that A. galli paralyzed and finally death, when exposed to the ethanol extract of C. fel-terrae leaves in the experimental condition. These effects are specific for substances which have anthelmintic activity [20]. Thereby, it indicates that $C$. fel-terrae leaves very potential as anthelmintic source. Other plant species also reported to have anthelmintic effects on A. galli. Subash et al. found at that $100 \mathrm{mg} / \mathrm{ml}$ of ethanol extracts of Eupatorium triplinerve and Alpinia galanga exhibited anthelmintic effect on A. galli with the death time of $2.54 \mathrm{hrs}$ and above $3.00 \mathrm{hrs}$, respectively [21]. Leaf methanol extract of Chinese violet (Asystasia gangeticum) at the experimental concentration of $100 \mathrm{mg} / \mathrm{ml}$ led to paralysis and death effects on A. galli at $0.27 \mathrm{hrs}$ and $0.55 \mathrm{hrs}$, respectively [22]. A. galli was paralyzed at $1.75 \mathrm{hrs}$ and death at $3.09 \mathrm{hrs}$, when exposed to $100 \mathrm{mg} / \mathrm{ml}$ of the leaf ethanol extract of Indonesian Allium fistulosum [23]. According to Kumar et al., methanol extracts of Cicer arietinum seeds $(100 \mathrm{mg} / \mathrm{ml})$ able to paralyze and kill A. galli at $0.14 \mathrm{hrs}$ and $0.64 \mathrm{hrs}$, respectively [24]. While $100 \mathrm{mg} / \mathrm{ml}$ of hydroalcoholic extract of Valeriana jatamansi leaves showed anthelmintic effects with the time of paralysis was $0.20 \mathrm{hrs}$ and the time of death was $0.45 \mathrm{hrs}$ [25]. In this case, although the anthelmintic effects of ethanol extract of $C$. fel-terrae on A. galli are weaker than the such plant extracts, but further studies are still needed to discovery its bioactive compounds.

The presence of phytochemical compounds such as polyphenols, tannins, saponins, and glycosides may contribute to anthelmintic activity of plant extracts [26-28]. Anthelmintic activity of other Linderniaceae species, such as Lindernia ruellioides (Closm.) Pennel., also reported by Goel et al. (2002) [29]. Potential anthelmintic activity of plant extracts may due to the presence of tannins content in high concentration [30]. Tannins is able to disturb the metabolism of ascaris species through oxidative phosphorylation reaction [31]. In addition, tannins can also bind to free protein nutrition which leads to larval starvation [32]. Flavonoids can interact with the free proteins of gastrointestinal host or glycoproteins on the worm's cuticula and blocking tubulin polymerization causing the worm death [33]. Saponins cause vacuolization and disintegration of the tegumental worm through changing of their cell membrane permeability [34]. Glycosides and steroids are antioxidant agents that decrease nitrate production, it leads to the inhibition of worm development [35]. The action mechanism of natural anthelmintic agents also involves inhibition of glucose up take system that causing the lost energy of worm [36]. Breaking of mucoplysaccharide membrane structure of helminths will restrict their movement which may cause paralysis and finally the worms death [37]. According to Kundu et al. (2015) and Swargiary and Roy (2012), phytochemicals are also involved in blocking of attachment of the parasitic worm to host by damaging of worm's tegumental surface [38]. The effects also involve the change of phosphatase enzymes in the tegument of parasites [39]. However, so far, action of mechanism of the ethanol extract of $C$. fel-terrae leave is unknown.

\section{CONCLUSION}

This study indicates the potential anthelmintic effects of leaf ethanol extract of C. fel-terra on A. galli.

\section{ACKNOWLEDGMENT}

We would like to thank the Universitas Sumatera Utara, Medan, Indonesia for their financial support by TALENTA Research Scheme 2016.

\section{REFERENCES}

1. World Health Organization. Water sanitation hygiene: Water related diseases: Ascariasis; 2001. Available from: http://www.who.int/ water sanitation health/diseases/ascariasis/en/. [Last accessed on 2016 Aug 17].

2. Indonesian Ministry of Health. Guidelines of Clinical Practices for Physician in Primary Health Care Facility. Jakarta: Indonesian Ministry of Health; 2014.

3. Arizono N, Yoshimura Y, Tohzaka N, Yamada M, Tegoshi T, Onishi K, et al. Ascariasis in Japan: Is pig-derived Ascaris infecting humans? Jpn 
J Infect Dis 2010;63(6):447-8

4. Tagboto S, Townson S. Antiparasitic properties of medicinal plants and other naturally occurring products. Adv Parasitol 2001;50:199-295.

5. van Balgooy MM. An update survey of Malesian seeds plants families. Reinwardtia 2010;13(2):171-81.

6. Rahmanzadeh R, Müller K, Fischer E, Bartels D, Borsch T. The linderniaceae and gratiolaceae are further lineages distinct from the scrophulariaceae (Lamiales). Plant Biol (Stuttg) 2005;7(1):67-78.

7. Tinton A. Smart Book of Medicinal Plants. $1^{\text {st }}$ ed. Jakarta: Agromedia Pustaka; 2008

8. Patilaya P, Husori DI. Preliminary study on the anthelmintic activity of the leaf ethanolic extract of Indonesian Curanga fel-terrae (Lour.) Merr. Int J Pharm Technol Res 2015;8(3):347-51.

9. Rodriguez JY, Craig TM. Parasites of Backyard Chickens. Clinician's Brief; 2015. p. 65-9. Available from: http:/www.cliniciansbrief.com/ article/parasites-backyard-chickens. [Last accessed on 2016 Oct 13]

10. Rahemo ZI, Hussain SS. Histological study on the body wall of Ascaridia galli (Nematoda). J Entomol Nematol 2009;1(6):74-82.

11. Tiwari P, Kumar B, Kaur M, Kaur G, Kaur H. Phytochemical screening and extraction: A review. Int Pharm Sci 2011;1(1):98-106.

12. Huang Y, De Bruyne T, Apers S, Ma Y, Claeys M, Pieters L, et al. Flavonoid glucuronides from Picria fel-terrae. Phytochemistry 1999;52(8):1701-3.

13. Zou JM, Wang LS, Ma XM, Shi RB, Guo YJ. Isolation and identification of a new cucurbitacin from Picria fel-terrae. Yao Xue Xue Bao 2004;39:910-2.

14. Huang Y, De Bruyne T, Apers S, Ma Y, Claeys M, Vanden Berghe D, et al. Complement-inhibiting cucurbitacin glycosides from Picria fel-terrae. J Nat Prod 1998;61(6):757-61.

15. Fang H, Ning DS, Liang XY. Studies on technology optimization for extracting triterpenoid saponins from Picria fel-terrae by multi-target grading method. J Chin Med Mater 2009;32(12):1902-5.

16. Sitorus $P$, Harahap U, Pandapotan M, Barus T. Isolation of $\beta$-sitosterol from n-hexane extract of Picria fel-terrae Lour. Leave and study of its antidiabetic effect in alloxan induced diabetic mice. Int J Pharm Technol Res 2014;6(1):137-41.

17. Kumarasingha R, Karpe AV, Preston S, Yeo TC, Lim DS, Tu CL, et al. Metabolic profiling and in vitro assessment of anthelmintic fractions of Picria fel-terrae Lour. Int J Parasitol Drugs Drug Resist 2016;6(6):171-8

18. Neves BJ, Andrade CH, Cravo PV. Natural products as leads in schistosome drug discovery. Molecules 2015;20(2):1872-903.

19. Enejoh OS, Suleiman MM, Ajanusi JO, Ambali SF. In vitro anthelmintic efficacy of extracts of Citrus aurantifolia (Christm) swingle fruit peels against Heligmosomoides bakeri ova and larvae. Int J Curr Pharm Res 2015;7(2):92-6.

20. Bi S, Goyal PK. Anthelmintic effect of natural plant (Carica papaya) extract against the gastrointestinal nematode, Ancylostoma caninum in mice. ISCA J Biol Sci 2012;1(1):2-6.

21. Subash KR, Rao NJ, Cheriyan BV, Bhaarati GM, Kumar KS. The anthelmintic activity of Eupatorium triplinerve and Alpinia galanga in Pheretima posthuma and Ascaridia galli: A comparative study. J Clin Diagn Res 2012;6(6):947-50.

22. Jiju V, Gorantla M, Chamundeeswari D. Evaluation of anthelmintic activity of methanolic extract of Asystasia gangeticum. Int J Pharm Life Sci 2013;4(6):2727-30

23. Husori DI, Bancin DY, Muhaimin, Bahri S, Patilaya P. Anthelmintic activity of ethanolic and aqueous extracts of Allium fistulosum L. Leaves on Ascaris lumbricoides. Int J Pharm Clin Res 2016;8(9):1310-3.

24. Kumar R, Solanki R, Triphati L. In vitro anthelmintic activity of seeds of Cicer arietinum L. Asian. J Chem 2013;25(9):5109-10.

25. Kour M, Singh H, Kaur J. Anthelmintic activity of hydroalcoholic extract of leaves of Valeriana jatamansi. World J Pharm Sci 2014;2(12):1741-5.

26. Olusegun-Joseph TS, Ofodile LN, Oguntoke T. In vitro evaluation of anthelmintic activity of crude extract of the leaves of Dalbergiella welwitschii. Int J Pharm Pharm Sci 2013;5 Suppl 1:32-3.

27. Paria S, Maity S, Mookerjee M. Phytochemial investigation and evaluation of anthelmintic activities of $V$. Negundo leaf extract. Int $\mathrm{J}$ Res Pharm Biomed Sci 2012;3:1143-6.

28. Joshi N, Bhatt S, Dhyani S, Nain J. Phytochemical screening of secondary metabolites of Argemone mexicana linn flowers. Int J Curr Pharm Res 2013;5:144-7.

29. Goel AK, Kulshreshtha DK, Dubey MP, Rajendran SM. Screening of Indian plants for biological activity: Part XVI. Indian J Exp Biol 2002;40(7):812-27.

30. Azaizeh H, Halahleh F, Abbas N, Markovics A, Muklada H, Ungar ED, et al. Polyphenols from Pistacia lentiscus and Phillyrea latifolia impair the exsheathment of gastro-intestinal nematode larvae. Vet Parasitol 2013;191(1-2):44-50.

31. Kumar BS, Lakshman K, Jayaveera KN, Velmurugan C, Manoj B, Sridhar SM. Anthelmintic activity of methanol extract of Amaranthus caudatus Linn. Internet J Food Saf 2010;12:127-9.

32. Jain P, Singh S, Singh SK, Verma SK, Kharya MD, Solanki S. Anthelmintic potential of herbal drugs. Int J Res Dev Pharm L Sci 2013;2(3):412-27

33. Hussain A, Sonkar AK, Ahmad MP, Wahab S. In vitro anthelmintic activity of Coleus aromaticus root in Indian adulth earthworm. Asian Pac J Trop Dis 2012;2 Suppl 1:425-7.

34. Wang GX, Han J, Zhao LW, Jiang DX, Liu YT, Liu XL. Anthelmintic activity of steroidal saponins from Paris polyphylla. Phytomedicine 2010;17(14):1102-5

35. Borba HR, Freire RB, Albuquerque AC, Cardoso ME, Braga IG, Almeida ST, et al. Anthelmintic comparative study of Solanum lycocarpum St. Hill extracts in mice naturally infected with Aspiculuris tetraptera. Nat Sci 2010;8(4):94-100.

36. Gaikwad SS, Kale AA, Jadhav BG, Deshpande NR, Salvekar JP. Anthelmintic activity of Cassia auriculata L. Extracts-In vitro study. J Nat Prod Plant Resour 2011;1(2):62-6.

37. Chandrashekhar CH, Latha KP, Vagdevi HM, Vaidya VP. Anthelmintic activity of the crudeextracts of Ficus racemosa. Int J Green Pharm 2008;2(2):100-3

38. Kundu S, Roy S, Nandi S, Ukil B, Lyndem LM. In vitro anthelmintic effects of Senna occidentalis (L.) Link (Leguminosae) on rat tapeworm Hymenolepis diminuta. Int J Pharm Pharm Sci 2015;7(6):268-72.

39. Swargiary A, Roy B. In vitro anthelmintic afficacy of Alpinia nigra and its bioactive compound, astragalin against Fasciolopsis buski. Int $\mathrm{J}$ Pharm Pharm Sci 2015;7(10):30-5. 